\title{
Proposed Maintenance Policy Design on Paving Molding Machine Using Reliability and Risk Centered Maintenance (RRCM) Method at PT XYZ
}

\section{Usulan Perancangan Kebijakan Pemeliharaan Pada Mesin Pencetak Paving Menggunakan Metode Reliability and Risk Centered Maintenance (RRCM) di PT XYZ}

\author{
I Gede Oka Mahendra ${ }^{1}$, Fransiskus Tatas Dwi Atmaji ${ }^{{ }^{*}}$, Judi Alhilman ${ }^{{ }^{*}}$ \\ ${ }^{1}$ Jurusan Teknik Industri, Fakultas Rekayasa Industri, Telkom University \\ Jl. Telekomunikasi No. 1, Terusan Buahbatu - Bojongsoang, Bandung, Indonesia, 40257 \\ email : Igedeokamahendra@student.telkomuniversity.ac.id, franstatas@telkomuniversity.ac.id, \\ alhilman@telkomuniversity.ac.id \\ doi: https://doi.org/10.31315/opsi.v14i2.5477
}

Received: $17^{\text {th }}$ September 2021; Revised: 18 nd October 2021; Accepted: $23^{\text {rd }}$ Oktober 2021; Available online: $21^{\text {st }}$ December 2021; Published regularly: December 2021

\begin{abstract}
PT. XYZ is a company engaged in construction and manufacturing. The company focuses on paving production. Where there is a problem with paving printing machines in carrying out production, there are many productions that do not reach the target or the production process does not run optimally. The purpose of this study is to find out the performance of paving molding machines, especially in the components that most often experience damage to paving molding machines. Based on historical data on machine damage, a paving molding machine is a machine that has had the highest frequency of damage for 5 years, because this machine operates continuously to meet production targets and paving demand from customers. Reliability and Risk Centered Maintenance (RRCM) methods to be used to analyze a historical engine malfunction. The results obtained in the form of 7 proposed maintenance tasks are 2 scheduled on-condition tasks, 3 scheduled restoration tasks, 2 scheduled waste tasks. In addition, the average maintenance time interval for pillow blocks is 7 months, iron molding is 11 months, and chain is 4 months. The total cost of proposed maintenance is lower than IDR 52,938,750 or 41.7\% compared to the existing maintenance cost of PT. XYZ. The development of this research is to increase the application of $R C M$ as a basis for maintaining the balance between preventive maintenance and corrective maintenance while optimizing maintenance costs to improve engine reliability by considering risk factors as an analysis.
\end{abstract}

Keywords: Reliability and Risk Centered Maintenance; Risk Matrix; Uncertainty Assessment

\section{ABSTRAK}

PT. XYZ adalah perusahaan yang bergerak di bidang konstruksi dan manufaktur. Perusahaan ini berfokus pada produksi paving. Dimana terjadi permasalahan terhadap mesin pencetak paving dalam melakukan produksi, adapun terdapat jumlah produksi yang tidak mencapai target atau proses produksi tidak berjalan secara maksimal. Tujuan dari penelitian ini yaitu untuk mengetahui kinerja mesin pencetak paving, terutama pada komponen yang paling sering mengalami kerusakan pada mesin pencetak paving. Berdasarkan data historis kerusakan mesin, mesin pencetak paving adalah mesin yang memiliki frekuensi kerusakan tertinggi selama 5 tahun, dikarenakan mesin ini beroperasi secara terus-menerus untuk memenuhi target produksi dan permintaan paving dari customer. Metode Reliability and Risk Centered Maintenance (RRCM) yang akan digunakan untuk menganalisis data historis kerusakan mesin. Hasil yang didapat berupa 7 proposed maintenance task yaitu 2 scheduled on-condition task, 3 scheduled restoration task, 2 scheduled discard task. Selain itu didapatkan interval waktu rata-rata pemeliharaan untuk pillow block selama 7 bulan, besi molding 11 bulan dan rantai 4 bulan. Total biaya maintenance usulan lebih rendah $R p 52.938 .750$ atau sebesar 41,7\% dibandingkan dengan biaya 
maintenance eksisting PT.XYZ. Pengembangan dari penelitian ini yaitu menggabungkan penerapan RCM sebagai dasar untuk menjaga keseimbangan antara preventive maintenance dan corrective maintenance sekaligus dapat mengoptimalkan biaya pemeliharaan guna meningkatkan keandalan mesin dengan mempertimbangkan faktor risiko sebagai analisisnya.

Kata Kunci: Keandalan dan Pemeliharaan Berpusat pada Risiko; Matriks Risiko; Penilaian Ketidakpastian

\section{PENDAHULUAN}

Sektor industri menjadi sektor penting dalam pembangunan perekonomian Indonesia. Salah satu industri yang memberikan banyak manfaat dan perubahan yaitu industri konstruksi dan manufaktur. Dalam industri manufaktur, mesin-mesin perlu dijaga atau dilakukan pemeliharaan supaya bisa digunakan dalam jangka waktu yang panjang. Selama proses produksi berlangsung mesin harus dipantau dengan baik untuk memastikan mesin berjalan sesuai jadwal, dan tidak ada kerusakan mendadak yang dapat mengganggu proses produksi (Atmaji \& Alhilman, 2018).

Pemeliharaan adalah suatu kegiatan yang dilakukan untuk mengembalikan fungsi suatu mesin atau sistem ke fungsi semula (Dhamayanti et al., 2016). Maintenance adalah kombinasi berbagai tindakan guna menjaga sebuah alat atau aset dengan cara memperbaiki hingga kondisi dapat diterima (Basanta et al., 2017). Pemeliharaan mesin adalah suatu kegiatan untuk mengembalikan fungsi suatu mesin, peralatan, atau sistem ke tingkat operasi semula untuk hasil yang lebih optimal (Afiva et al., 2019).

Saat mesin beroperasi selama 24 jam dalam sehari, sistem pemeliharaan mesin harus dipertimbangkan untuk menjamin kelanjutan proses produksi tersebut (Alhilman et al., 2017). Sistem pemeliharaan dibagi menjadi 2 jenis, yaitu preventive maintenance dan corrective maintenance (Márquez, 2007). Corrective maintenance adalah kegiatan pemeliharaan yang dilakukan setelah komponen mengalami kerusakan, biasanya dilakukan saat mesin sudah berhenti untuk mengembalikan sistem ke fungsi semula. Sedangkan preventive maintenance adalah kegiatan pemeliharaan yang dilakukan sebelum komponen mengalami kerusakan dan bertujuan untuk mencegah terjadinya kegagalan dari mesin atau komponen tersebut (Holgado et al., 2016).

PT. XYZ adalah perusahaan yang bergerak dalam industri paving. Dalam proses produksinya, perusahaan memiliki satu mesin pencetak paving yang digunakan untuk memproduksi paving. Mesin tersebut beroperasi secara terus-menerus karena disesuaikan dengan target dan permintaan konsumen. Mesin yang beroperasi terus-menerus dapat menyebabkan keandalan mesin akan menurun dan menyebabkan mesin mengalami rusak.

PT. XYZ sering mengalami masalah pada kerusakan mesin, salah satunya kinerja mesin tidak maksimal yang menyebabkan target produksi dan permintaan paving tidak bisa tercapai. Mesin pencetak paving memiliki frekuensi kerusakan yang paling tinggi selama 5 tahun. Dapat dilihat pada gambar 1, mesin pencetak paving memberikan pengaruh sangat besar terhadap proses produksi. Jika terjadi kerusakan maka kegiatan produksi akan berhenti dan tidak akan menghasilkan output.

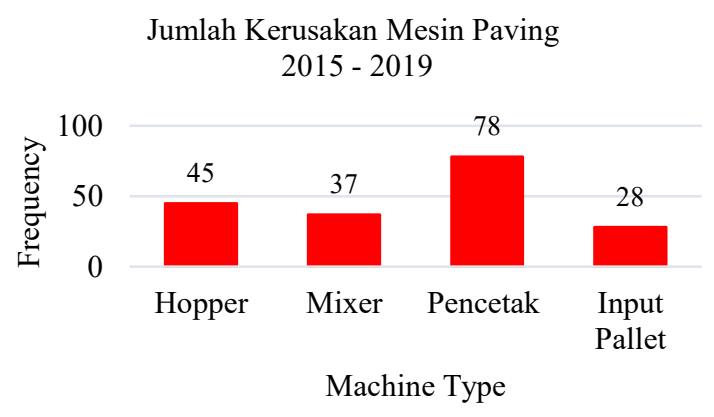

Gambar 1. Grafik Frekuensi Kerusakan Mesin

Kegiatan pemeliharaan yang dilakukan oleh perusahaan saat ini berupa corrective maintenance, yaitu melakukan kegiatan pemeliharaan jika mesin tidak bisa beroperasi saat itu juga. Hal ini yang menyebabkan downtime mesin meningkat sehingga kinerja atau keandalan mesin akan menurun. Kegiatan corrective maintenance akan menjadi penyebab borosnya biaya pada saat melakukan pemeliharaan pada mesin (Joel Levitt, 2008).

Untuk mengoptimalkan kinerja mesin pencetak paving, perusahaan diharuskan menyusun jadwal kegiatan pemeliharaan yang 
dapat meningkatkan performansi mesin dalam melakukan produksi. Salah satu metode untuk menyusun penjadwalan pemeliharaan mesin yaitu metode Reliability Centered Maintenance (RCM). Beberapa hasil penelitian terdahulu tentang kebijakan maintenance yaitu jadwal pemeliharaan, interval waktu perbaikan komponen, dan meminimalkan biaya pemeliharaan yang dapat dijadikan peneliti sebagai acuan dalam penelitian ini. Menurut (Igba et al., 2013) menjelaskan bahwa "Metode RCM merupakan cara mengetahui penyebab dari waktu henti pada komponen yang mengalami kegagalan dan kinerja yang buruk melalui pencegahan kegagalan serta melakukan pendekatan terkait kegiatan pemeliharaan pada komponen yang mengalami kegagalan".

Menurut (Okwuobi et al., 2018) menjelaskan bahwa "RCM membahas mengenai rekomendasi terkait penerapan pemeliharaan yang terpusat pada sistem guna meningkatkan keandalan mesin saat produksi berlangsung dengan maksud memberi program pemeliharaan preventif baru". Penelitian yang dilakukan (Alrifaey et al., 2020) hasil penelitian ini menunjukkan "Untuk mendapatkan jadwal kebijakan pemeliharaan maksimal untuk seluruh sistem, maka diperlukan langkah-langkah penerapan metode RCM yaitu pembuatan prioritas failure mode untuk setiap sistem penyusun mesin hingga tahap keputusan dilakukan pemeliharaan pada setiap sistem".

Penelitian yang dilakukan (Kullawong \& Butdee, 2015) hasil penelitian ini menunjukkan "RCM dapat memberikan hasil berupa pengembangan jadwal pemeliharaan dan manajemen biaya pemeliharaan di Plant Hard Chrome Plating". Penelitian yang dilakukan (Fang et al., 2019) hasil penelitian ini menunjukkan "Penerapan metode RCM dapat memberikan pengembangan strategi pemeliharaan yang sesuai dengan masalah pada komponen kritis, sehingga pengoperasian kereta api berjalan lancar". Menurut (Gupta et al., 2016) menjelaskan bahwa "Metode RCM dipakai dalam memilih strategi pemeliharaan yang sesuai pada tiap failure mode. Untuk menentukan komponen yang sering mengalami kegagalan dilakukan dengan perhitungan RPN. RPN merupakan salah satu cara untuk menentukan komponen kritis dari failure mode pada sistem".
Penelitian yang dilakukan (Sinha \& Mukhopadhyay, 2015) hasil penelitian ini menunjukkan "Metode RCM memfokuskan penerapan pemeliharaan yang berpusat pada keandalan sistem guna meningkatkan kinerja mesin cone crusher dalam melakukan produksi”. Menurut (Niu et al., 2010) menjelaskan bahwa "Penerapan strategi RCM mampu meningkatkan kegiatan pemeliharaan dan mendapat keuntungan biaya pemeliharaan lebih optimal”. Menurut (Khorshidi et al., 2015) menjelaskan bahwa "RCM adalah proses mengambil keputusan sistematis guna menjaga keseimbangan antara tindakan pemeliharaan preventif dan korektif sekaligus memilih rencana pemeliharaan hemat biaya guna meningkatkan keandalan mesin".

Penelitian yang dilakukan (Atmaji et al., 2017) pada sub-sistem kritis mesin pesawat menjelaskan bahwa "Tujuan utama RCM adalah membangun prioritas mengenai desain yang mampu mendukung kegiatan pemeliharaan preventif dan mendapat informasi yang bermanfaat untuk meningkatkan desain komponen dengan keandalan, ketersediaan, dan pemeliharaan". Penelitian yang dilakukan (Atmaji, 2015) hasil penelitian ini menunjukkan "Penerapan metode RCM menghasilkan jadwal pemeliharaan, interval waktu penggantian yang optimum dan total biaya pemeliharaan yang minimum untuk tiap komponen kritis".

Belum adanya jadwal pemeliharaan, interval waktu pemeliharaan, dan biaya pemeliharaan yang masih tinggi, maka peneliti mengusulkan menerapkan metode RRCM dalam menentukan usulan kebijakan pemeliharaan yang lebih optimal. Menurut (Selvik \& Aven, 2011) menjelaskan bahwa "RRCM memiliki tujuan untuk menciptakan metode pemeliharaan yang akurat, fokus serta optimal agar mendapat keandalan (reliability) fasilitas yang maksimal dengan mengacu pada faktor risiko sebagai salah satu analisisnya".

\section{METODE}

Penelitian ini berfokus pada komponen kritis mesin pencetak paving. Pada gambar 2, langkah pertama dilakukan system breakdown structure. Tujuan dilakukan system breakdown structure yaitu untuk mengetahui komponen penyusun pada mesin pencetak paving. Selanjutnya dilakukan penentuan komponen 
kritis menggunakan risk matrix. Penentuan risk matrix yang digunakan menurut standar (AS/NZS 4360, 1999). Tujuan dilakukannya risk matrix yaitu untuk mengetahui sub-sistem kritis pada mesin dengan mengklasifikasikan dampak dan kemungkinan risiko yang terjadi pada saat mesin rusak. Setelah itu dilakukan perhitungan TTR, TTF, dan TBF untuk mengetahui distribusi yang terpilih untuk setiap komponen kritis. Selanjutnya dilakukan dengan menghitung MTTR, MTTF, dan MTBF. Data MTTR, MTTF, dan MTBF dibutuhkan untuk mengetahui interval waktu maintenance dari setiap komponen kritisnya. Proposed maintenance task dan interval waktu maintenance yang akan dijadikan usulan kepada perusahaan dalam penentuan untuk menerapkan kebijakan maintenance-nya.

MTBF merupakan parameter dari keandalan sistem atau dapat digunakan untuk membandingkan sistem atau desain yang berbeda (Lienig \& Bruemmer, 2017). MTTF adalah rata-rata dari selang waktu antara kerusakan komponen yang pertama dengan kerusakan selanjutnya. Sedangkan MTTR adalah waktu yang diperlukan untuk memperbaiki komponen yang rusak hingga komponen berfungsi kembali (Atmaji, 2015). Berikut rumus untuk menentukan setiap distribusi yaitu:

1. Distribusi Normal

$$
\text { MTTF }=\mu
$$

2. Distribusi Weibull

$$
\text { MTFF }=\eta \times \Gamma\left(1+\frac{1}{\beta}\right)
$$

3. Distribusi Eksponensial

$$
\mathrm{MTFF}=\frac{1}{\lambda}
$$

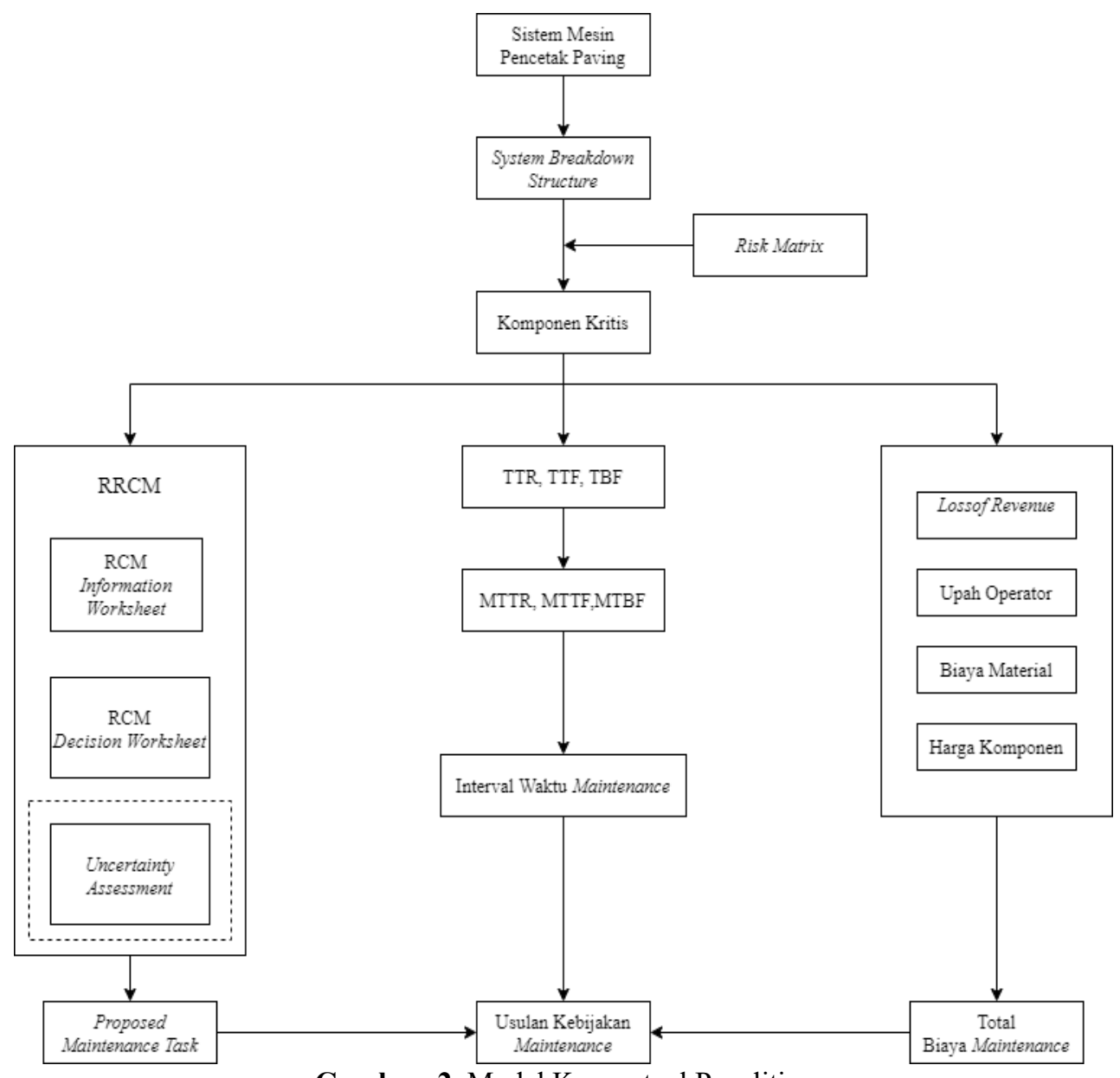

Gambar 2. Model Konseptual Penelitian 
Setelah mendapatkan hasil MTTR, MTTF, dan MTBF, langkah selanjutnya membuat RCM Information Worksheet untuk setiap komponen kritis mesin pencetak paving. Selanjutnya, dilakukan pembuatan RCM Decision Worksheet yang akan digunakan untuk menetapkan proposed maintenance task yang sesuai untuk setiap komponen kritis mesin pencetak paving. Kemudian dilanjutkan melakukan perhitungan untuk setiap proposed maintenance task yang terpilih sehingga mendapatkan interval waktu pemeliharaan untuk setiap komponen kritis pada mesin pencetak paving. Garis putus-putus pada kerangka RRCM yaitu uncertainty assessment merupakan penambahan variabel baru berupa risiko.

Menurut (Márquez, 2007) menjelaskan bahwa "RCM diklasifikasikan menjadi 3 kategori proposed maintenance task yaitu, pertama scheduled on-condition task merupakan pemeliharaan yang dilakukan dengan mengamati atau mengukur kinerja komponen pada saat mesin sedang beroperasi apabila terdapat tanda-tanda kerusakan pada komponen atau sistem tersebut. Kedua scheduled restoration task merupakan pemeliharaan melalui perbaikan sistem pada jadwal tertentu sebelum batasan usianya tanpa melihat kondisi sistem saat itu, yang membuat sistem perlu diberhentikan untuk sementara. Ketiga scheduled discard task merupakan pemeliharaan dengan cara penggantian suku cadang ataupun komponen tertentu dari sebuah sistem sebelum batasan usianya tanpa memperhatikan kondisi suku cadang ataupun komponen sistem terkait". Berikut persamaan yang digunakan dalam menentukan interval waktu scheduled restoration task dan scheduled discard task:

$\mathrm{TM}=\eta \times\left[\frac{\mathrm{Cm}}{\mathrm{cf}(\beta-1)}\right]^{\frac{1}{\beta}}$

$\mathrm{Cm}=\mathrm{PM} \cos t+$ Downtime cost $+\mathrm{Cw}(5)$

$\mathrm{Cf}=\mathrm{Cr}+\mathrm{MTTR}(\mathrm{Co}+\mathrm{Cw})$

Keterangan :

TM : Interval waktu maintenance dalam satuan jam

$\mathrm{Cm}$ : Total biaya maintenance

Cf : Biaya perbaikan sistem atau penggantian komponen dari sistem

$\mathrm{Cw}$ : Upah engineer

$\mathrm{Cr}$ : Biaya penggantian atau perbaikan kerusakan suku cadang

Co : Biaya kerugian produksi.

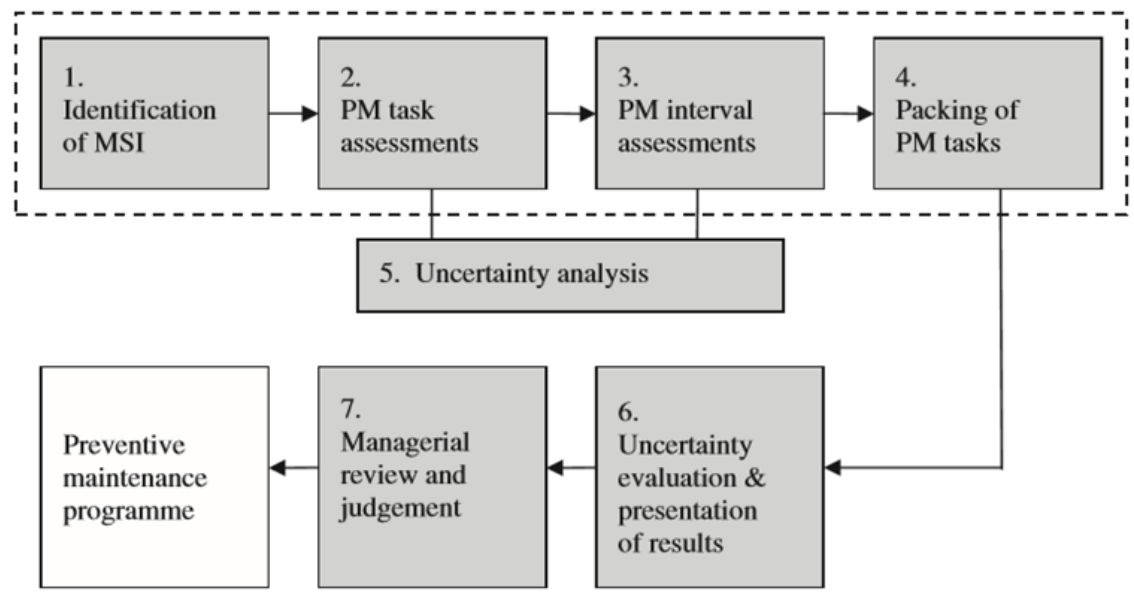

Gambar 3. Kerangka Metode RRCM

(Sumber : Selvik \& Aven, 2011)

Gambar 3, merupakan langkah-langkah dalam menerapkan metode RRCM. Empat kotak pertama adalah bagian dari RCM. Lalu kotak kelima adalah langkah pengintegrasian penilaian dari faktor risiko (Selvik \& Aven, 2011). Dalam pengintegrasian faktor risiko, dilakukan dengan identifikasi faktor ketidakpastian yang berkaitan dengan tingkat ketidakpastian, tingkat sensitivitas, dan tingkat kepentingan, Setelah semua hasil didapat, selanjutnya dilakukan perluasan Extended RRCM worksheet untuk mengikutsertakan 
seluruh hasil dari penilaian pada langkahlangkah yang dipaparkan sebelumnya.

\section{HASIL DAN PEMBAHASAN}

\subsection{System Breakdown Structure (SBS)}

Langkah pertama yang dilakukan dalam penerapan RRCM adalah System Breakdown
Structure (SBS). Berikut merupakan SBS dari mesin pencetak paving:

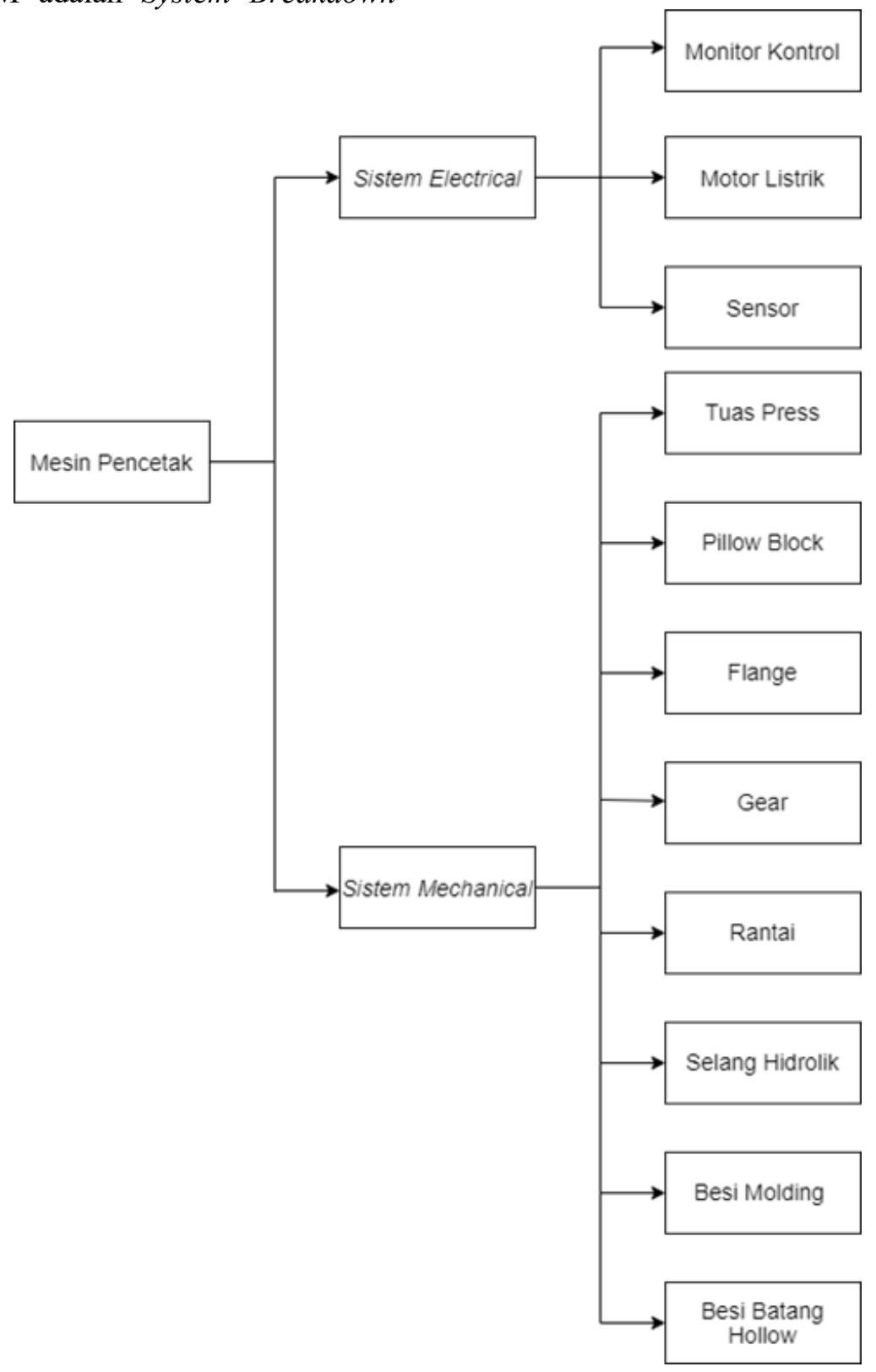

Gambar 4. SBS Mesin Pencetak Paving

Pada gambar 4, mesin pencetak paving memiliki sub-sistem elektrik dan mekanik. Pada sub-sistem elektrik terdapat komponen seperti monitor kontrol, motor listrik, dan sensor. Sedangkan untuk sub-sistem mekanik terdapat komponen seperti tuas press, pillow block, flange, gear, rantai, selang hidrolik, besi molding, dan batang besi hollow.

\subsection{Penentuan Komponen Kritis}

Selanjutnya dilakukan penentuan komponen kritis menggunakan risk matrix. Risk matrix diklasifikasikan menjadi empat bagian 
berdasarkan warna, yang terdiri dari warna hijau, kuning, jingga (orange), dan merah. Komponen yang berada pada warna hijau memiliki kondisi yang aman, komponen tersebut tidak menimbulkan dampak yang besar bagi perusahaan. Komponen yang berada pada warna kuning akan menimbulkan dampak bagi perusahaan tetapi tidak terlalu signifikan.
Komponen yang berada pada warna orange dan merah memiliki kondisi tidak aman atau mengalami kegagalan fungsi yang dapat berpengaruh secara signifikan terhadap kerugian yang diterima perusahaan (AS/NZS 4360, 1999).

Tabel 1. Risk Matrix Sub-sistem Mesin Pencetak Paving

\begin{tabular}{|c|c|c|c|c|c|}
\hline \multirow{2}{*}{ Likelihood } & \multicolumn{5}{|c|}{ Severity } \\
\hline & Insignificant & Minor & Moderate & Major & Catastrophic \\
\hline $\begin{array}{l}\text { Almost } \\
\text { Certain }\end{array}$ & & & Rantai & & \\
\hline Likely & & & Besi Molding & & \\
\hline Possible & & $\begin{array}{c}\text { Sensor, } \\
\text { Selang } \\
\text { Hidrolik, } \\
\text { Besi Batang } \\
\text { Hollow }\end{array}$ & Pillow Block & & \\
\hline Unlikely & & $\begin{array}{c}\text { Flange, } \\
\text { Gear }\end{array}$ & & & \\
\hline Rare & $\begin{array}{l}\text { Motor } \\
\text { Listrik }\end{array}$ & $\begin{array}{c}\text { Monitor } \\
\text { Kontrol, } \\
\text { Tuas Press }\end{array}$ & & & \\
\hline
\end{tabular}

Tabel 2. Hasil Uji Distribusi TTR

\begin{tabular}{ccccc}
\hline Komponen & Distribusi & $\begin{array}{c}\text { AD } \\
\text { Value }\end{array}$ & $\begin{array}{c}\text { P- } \\
\text { Value }\end{array}$ & $\begin{array}{c}\text { Distribusi } \\
\text { Terpilih }\end{array}$ \\
\hline Pillow & Normal & 0,373 & 0,368 & \\
Block & Exponential & 5,706 & $<0,003$ & Normal \\
& Weibull & 0,393 & $>0,250$ & \\
& & & & \\
Besi & Normal & 0,233 & 0,739 & \\
Molding & Exponential & 4,013 & $<0,003$ & Weibull \\
& Weibull & 0,214 & $>0,250$ & \\
& & & & \\
& & & & \\
Rantai & Normal & 0,166 & 0,927 & \\
& Exponential & 6,898 & $<0,003$ & Normal \\
& Weibull & 0,232 & $>0,250$ & \\
& & & & \\
\hline
\end{tabular}

Berdasarkan tabel 1, didapatkan hasil dari perhitungan menggunakan risk matrix, terdapat 3 komponen kritis dari mesin pencetak paving yaitu pillow block, besi molding, dan rantai. Selanjutnya ke-3 komponen tersebut perlu dilakukan tindakan permeliharaan yang lebih.

\subsection{Perhitungan Nilai MTTR, MTTF, dan MTBF}

Penentuan distribusi dilakukan menggunakan software Minitab 19. Dalam menentukan distribusi yang terpilih bisa melihat nilai Anderson-Darling (AD) dan nilai P-Value. Nilai AD terkecil akan mewakili penyebaran data yang diuji dan nilai P-Value merupakan parameter untuk menerima ataupun menolak hipotesis. P-Value $>\alpha$, maka $\mathrm{H} 0$ diterima. Tingkat kepercayaan yang digunakan yakni $95 \%$.

Tabel 2, 3, dan 4 menunjukkan distribusi yang dipilih untuk data waktu kerusakan, waktu perbaikan, dan waktu henti.

Tabel 3. Hasil Uji Distribusi TTF

\begin{tabular}{ccccc}
\hline Komponen & Distribusi & $\begin{array}{c}\text { AD } \\
\text { Value }\end{array}$ & $\begin{array}{c}\text { P- } \\
\text { Value }\end{array}$ & $\begin{array}{c}\text { Distribusi } \\
\text { Terpilih }\end{array}$ \\
\hline \multirow{2}{*}{ Pillow } & Normal & 0,364 & 0,382 & \\
Block & Exponential & 1,604 & 0,020 & Weibull \\
& Weibull & 0,349 & $>0,25$ & \\
& & & 0 & \\
Besi & Normal & 0,315 & 0,493 & \\
Molding & Exponential & 2,274 & 0,004 & Weibull \\
& Weibull & 0,298 & 0,25 & \\
& & & 0 & \\
& & & 0,097 & \\
Rantai & Normal & 0,610 & $<0,00$ & Weibull \\
& Exponential & 3,831 & 3 & \\
& Weibull & 0,591 & 0,118 & \\
\hline
\end{tabular}


Tabel 4. Hasil Uji Distribusi TBF

\begin{tabular}{ccccc}
\hline \multirow{2}{*}{ Komponen } & Distribusi & $\begin{array}{c}\text { AD } \\
\text { Value }\end{array}$ & $\begin{array}{c}\text { P- } \\
\text { Value }\end{array}$ & $\begin{array}{c}\text { Distribusi } \\
\text { Terpilih }\end{array}$ \\
\hline \multirow{2}{*}{ Pillow } & Normal & 0,364 & 0,382 & \\
Block & Exponential & 1,606 & 0,020 & Weibull \\
& Weibull & 0,349 & $>0,250$ & \\
Besi & Normal & 0,315 & 0,493 & \\
Molding & Exponential & 2,276 & 0,004 & Weibull \\
& Weibull & 0,298 & $>0,250$ & \\
\multirow{2}{*}{ Rantai } & Normal & 0,609 & 0,097 & \\
& Exponential & 3,833 & $<0,003$ & Weibull \\
& Weibull & 0,591 & 0,118 & \\
\hline
\end{tabular}

Tabel 5. Hasil Perhitungan MTTR

\begin{tabular}{cccc}
\hline Komponen & $\begin{array}{c}\text { Distribusi } \\
\text { Terpilih }\end{array}$ & $\Gamma\left(\frac{1}{\beta}+1\right)$ & $\begin{array}{c}\text { MTTR } \\
\text { (Hour) }\end{array}$ \\
\hline $\begin{array}{c}\text { Pillow } \\
\text { Block }\end{array}$ & Normal & - & 3,2 \\
$\begin{array}{c}\text { Besi } \\
\text { Molding } \\
\text { Rantai }\end{array}$ & Weibull & 1.1345 & 2,4 \\
\hline
\end{tabular}

Tabel 6. Hasil Perhitungan MTTF

\begin{tabular}{cccc}
\hline Komponen & $\begin{array}{c}\text { Distribusi } \\
\text { Terpilih }\end{array}$ & $\Gamma\left(\frac{1}{\beta}+1\right)$ & $\begin{array}{c}\text { MTTF } \\
\text { (Hour) }\end{array}$ \\
\hline $\begin{array}{c}\text { Pillow Block } \\
\text { Besi }\end{array}$ & Weibull & 1.51 & 3320,8 \\
$\begin{array}{c}\text { Molding } \\
\text { Rantai }\end{array}$ & Weibull & 1.33 & 3691,9 \\
\hline
\end{tabular}

Tabel 7. Hasil Perhitungan MTBF

\begin{tabular}{cccc}
\hline Komponen & $\begin{array}{c}\text { Distribusi } \\
\text { Terpilih }\end{array}$ & $\Gamma\left(\frac{1}{\beta}+1\right)$ & $\begin{array}{c}\text { MTTF } \\
\text { (Hour) }\end{array}$ \\
\hline $\begin{array}{c}\text { Pillow Block } \\
\text { Besi }\end{array}$ & Weibull & 1.51 & 3324,1 \\
$\begin{array}{c}\text { Molding } \\
\text { Rantai }\end{array}$ & Weibull & 1.33 & 3694,6 \\
\hline
\end{tabular}

Selanjutnya dilakukan perhitungan MTTR, MTTF, dan MTBF untuk setiap komponen kritis menggunakan software AvSim+ 9.0 untuk mencari parameter untuk setiap distribusi komponen kritis.

Tabel 5, nilai MTTR untuk komponen pillow block adalah 3,2 jam, komponen besi molding adalah 2,4 jam, dan komponen rantai adalah 1,1 jam. Pada Tabel 6 nilai MTTF untuk komponen pillow block adalah 3320,8 jam, komponen besi molding adalah 3691,9 jam, dan komponen rantai adalah 2147,6 jam. Pada Tabel 7 nilai MTBF untuk komponen pillow block adalah 3324,1 jam, komponen besi molding adalah 3694,6 jam, dan komponen rantai adalah 2148,9 jam.

\subsection{Perhitungan RRCM}

RCM Information Worksheet berisikan function, functional failure, failure mode, dan failure effect tiap komponen kritis mesin pencetak paving. Langkah selanjutnya, dilakukan pembuatan RCM Decision Worksheet guna mendapatkan kebijakan pemeliharaan berupa proposed maintenance task yang sesuai untuk setiap komponen kritis mesin pencetak paving. Penentuan RCM Decision Worksheet dilakukan dengan consequence evaluation pada setiap failure mode yang sudah diidentifikasi dan diisi langsung oleh engineer PT. XYZ, untuk pengisiannya mengikuti langkah dari (Rahmadhanty et al., 2019). Selanjutnya dilakukan perhitungan interval waktu pemeliharaan berdasarkan proposed maintenance task yang dipilih. Setelah selesai menentukan proposed maintenance task dan interval waktu pemeliharaan untuk setiap komponen kritis, selanjutnya dilakukan analisis uncertainty assessment. Pada uncertainty assessment, faktor ketidakpastian menjadi salah satu bentuk risiko. Faktor risiko ini akan mempengaruhi hasil pengambilan keputusan akhir dalam tugas pemeliharaan yang diusulkan. Untuk mengintegrasikan hasil penilaian ketidakpastian ini ke dalam keputusan pemeliharaan yang diusulkan, peneliti memperluas lembar kerja RCM dengan memasukkan semua hasil penilaian dari uncertainty assessment.

Terdapat 2 faktor ketidakpastian yang memiliki peran penting dalam mengambil keputusan akhir untuk usulan proposed maintenance task. Adapun kedua faktor itu adalah degree of uncertainty dan degree of sensitivity (Selvik \& Aven, 2011). Jika pada failure mode untuk setiap komponen kritis memiliki penilaian degree of uncertainty high dan pada degree of sensitivity memiliki penilaian high, maka dapat disimpulkan degree of importance menghasilkan nilai high. Jika didapatkan hasil dari degree of importance memiliki penilaian "high" maka dapat mengubah proposed maintenance task dan interval waktu pemeliharaan yang sudah direkomendasikan sebelumnya.

Tabel 8, memberikan informasi yaitu menggabungkan lembar kerja keputusan RCM 
dengan penilaian ketidakpastian yang menghasilkan kerangka Extended RRCM Worksheet. Dengan menggunakan alat bantu RCM Decision Worksheet dan penilaian faktor ketidakpastian, peneliti memperoleh hasil berupa Scheduled On-condition Task untuk komponen pillow block dilakukan kegiatan pemeliharaan sebagian besar dengan mengamati atau mengukur kinerja komponen. sedangkan Schedule Discard Task untuk komponen pillow block dilakukan kegiatan pemeliharaan dengan cara penggantian suku cadang komponen.
Pada tabel 9, didapatkan hasil berupa Scheduled Restoration Task untuk komponen besi molding, maka kegiatan pemeliharaan melalui perbaikan sistem pada jadwal tertentu perlu diberhentikan untuk sementara

Pada Tabel 10, didapatkan hasil berupa Scheduled On-condition Task untuk komponen rantai dilakukan kegiatan pemeliharaan sebagian besar dengan mengamati atau mengukur kinerja komponen. sedangkan Schedule Discard Task untuk komponen rantai dilakukan kegiatan pemeliharaan dengan cara penggantian suku cadang komponen

Tabel 8. Hasil Lembar Kerja Keputusan Extended RRCM untuk Pillow Block

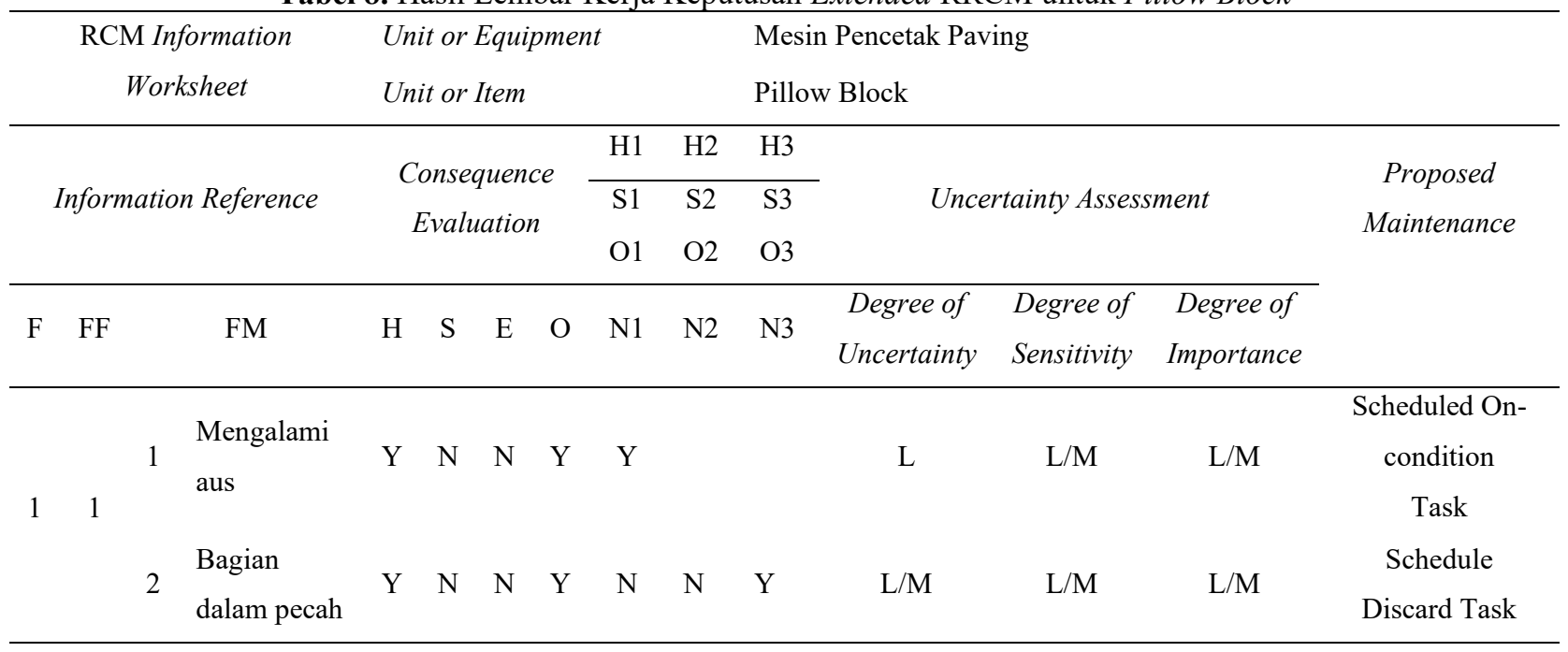

Tabel 9. Hasil Lembar Kerja Keputusan Extended RRCM untuk Rantai

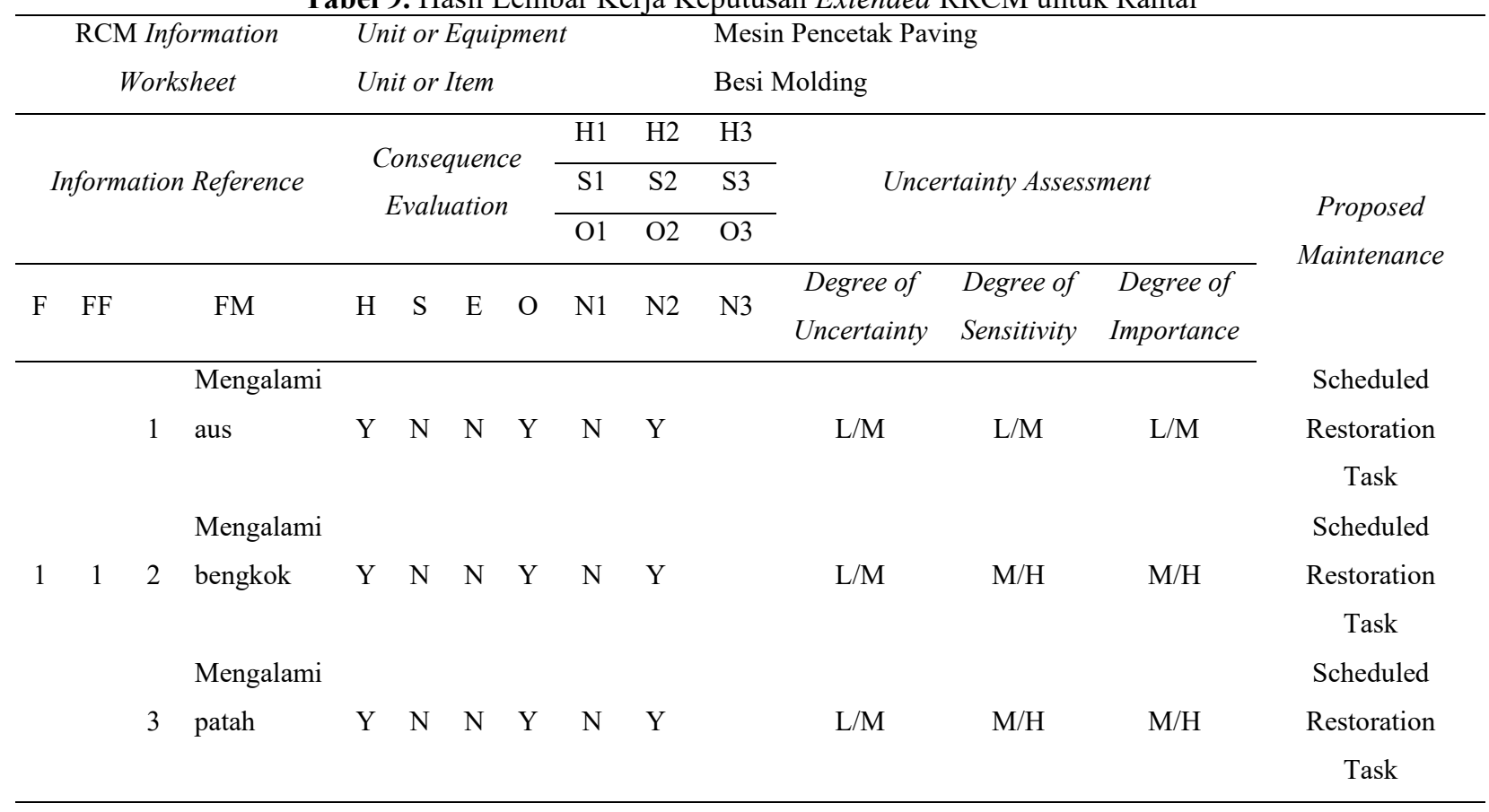


Tabel 10. Hasil Lembar Kerja Keputusan Extended RRCM untuk Besi Molding

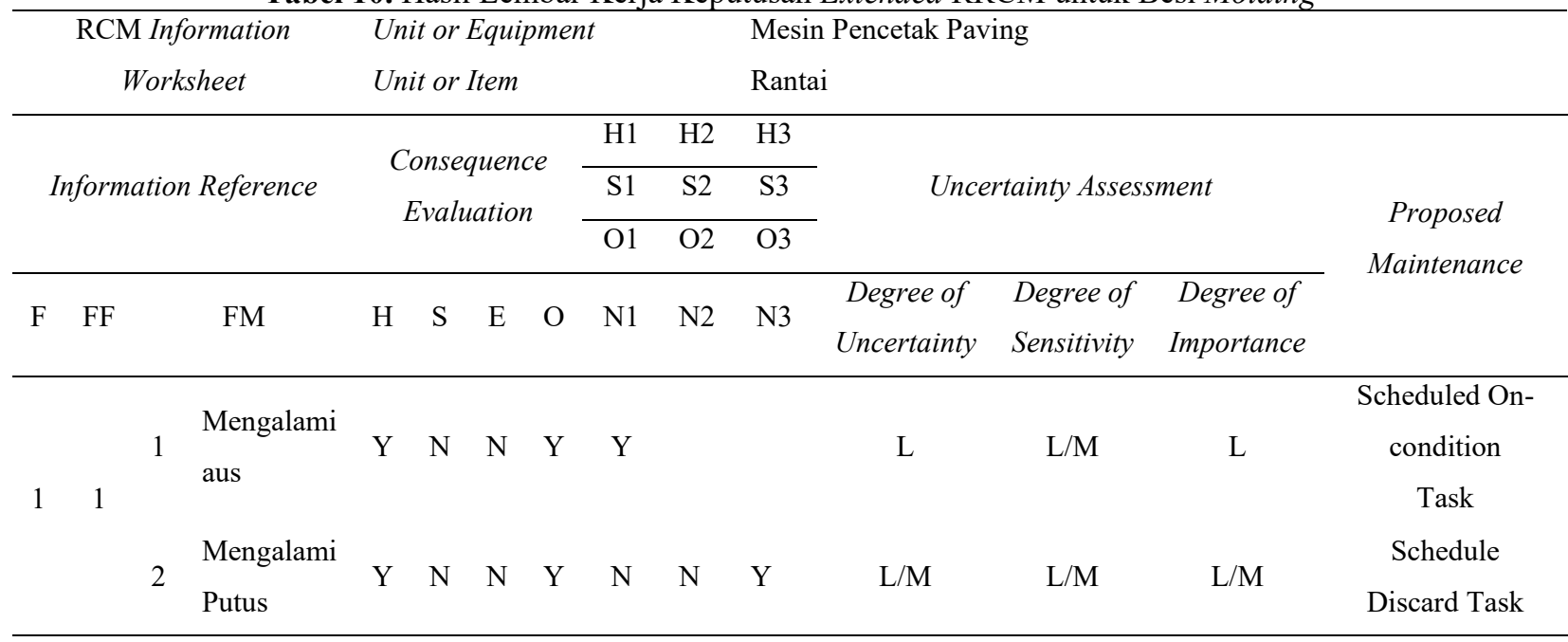

Tabel 8, 9, dan 10 merupakan hasil dari Extended RRCM Worksheet. Pada uncertainty assessment tidak terdapat failure mode yang memiliki penilaian "high" pada degree of importance. Sehingga usulan proposed maintenance task yang diusulkan tidak lagi dilakukan perubahan.

Tabel 11, 12, dan 13 merupakan hasil interval waktu pemeliharaan yang diusulkan dan tugas yang diusulkan untuk setiap komponen kritis. Untuk komponen pillow block interval waktu pemeliharaan dilakukan setiap 7 bulan sekali dengan melakukan pengecekan pada pillow block yang bertujuan mencegah terjadinya aus dan melakukan pergantian setiap 9 bulan sekali pada komponen pillow block yang mengalami pecah bagian dalam. Untuk komponen besi molding dilakukan restorasi selama 11 bulan sekali yang bertujuan mencegah terjadinya aus, mengalami bengkok, dan mengalami patah pada sekat besi molding. Untuk komponen rantai interval waktu pemeliharaan dilakukan setiap 4 bulan sekali dengan melakukan pengecekan pada rantai yang bertujuan mencegah terjadinya aus dan melakukan pergantian setiap 8 bulan sekali pada komponen rantai yang mengalami putus.

Pada tabel 14 menunjukkan biaya maintenance eksisting untuk setiap fungsi kegagalan dari setiap komponen kritis. Frekuensi Maintenance eksisting diperoleh dari engineer atau data umur komponen. Sedangkan pada tabel 15 menunjukan biaya maintenance usulan yang didapat pada kebijakan pemeliharaan yang telah ditentukan sebelumnya, yaitu dengan interval waktu pemeliharaan setiap komponen kritis. Untuk frekuensi maintenance usulan diperoleh dari lamanya sistem beroperasi selama setahun dalam satuan jam dibagi dengan interval waktu maintenance yang telah diperoleh.

Tabel 11. Interval Waktu Scheduled On-condition

\begin{tabular}{|c|c|c|c|}
\hline \multicolumn{4}{|c|}{ Task } \\
\hline Komponen & $\begin{array}{l}\text { Usulan Tugas } \\
\text { Pemeliharaan }\end{array}$ & $\begin{array}{c}\text { Interval } \\
\text { (Jam) }\end{array}$ & $\begin{array}{l}\text { Interval } \\
\text { (Bulan) }\end{array}$ \\
\hline $\begin{array}{l}\text { Pillow } \\
\text { Block }\end{array}$ & $\begin{array}{c}\text { Do the } \\
\text { scheduled on- } \\
\text { condition task } \\
\text { Melakukan } \\
\text { pengecekan } \\
\text { berkala pada } \\
\text { pillow block }\end{array}$ & 1662,0 & 7 \\
\hline Rantai & $\begin{array}{l}\text { Do the } \\
\text { scheduled on- } \\
\text { condition task } \\
\text { Melakukan } \\
\text { pengecekan } \\
\text { berkala pada } \\
\text { rantai dalam }\end{array}$ & 1074,5 & 4 \\
\hline
\end{tabular}

Tabel 12. Interval Waktu Scheduled Restoration Task

\begin{tabular}{|c|c|c|c|}
\hline Komponen & $\begin{array}{l}\text { Usulan Tugas } \\
\text { Pemeliharaan }\end{array}$ & $\begin{array}{l}\text { Interval } \\
\text { (Jam) }\end{array}$ & $\begin{array}{l}\text { Interval } \\
\text { (Bulan) }\end{array}$ \\
\hline $\begin{array}{c}\text { Besi } \\
\text { Molding }\end{array}$ & $\begin{array}{c}\text { Do the } \\
\text { scheduled } \\
\text { restoration task } \\
\text { Melakukan } \\
\text { perbaikan pada } \\
\text { komponen } \\
\text { Besi Molding }\end{array}$ & 2568,9 & 11 \\
\hline
\end{tabular}


Opsi

Vol 14 No 2 December 2021

Tabel 13. Interval Waktu Scheduled Discard Task

\begin{tabular}{|c|c|c|c|}
\hline Komponen & $\begin{array}{l}\text { Usulan Tugas } \\
\text { Pemeliharaan }\end{array}$ & $\begin{array}{c}\text { Interval } \\
\text { (Jam) }\end{array}$ & $\begin{array}{l}\text { Interval } \\
\text { (Bulan) }\end{array}$ \\
\hline $\begin{array}{l}\text { Pillow } \\
\text { Block }\end{array}$ & $\begin{array}{c}\text { Do the } \\
\text { scheduled } \\
\text { discard task } \\
\text { Melakukan } \\
\text { pergantian } \\
\text { pada } \\
\text { komponen } \\
\text { pillow block }\end{array}$ & 2151,6 & 9 \\
\hline Rantai & $\begin{array}{c}\text { Do the } \\
\text { scheduled } \\
\text { discard task } \\
\text { Melakukan } \\
\text { pergantian } \\
\text { pada } \\
\text { komponen } \\
\text { rantai }\end{array}$ & 1850,8 & 8 \\
\hline
\end{tabular}

\subsection{Perhitungan Biaya Maintenance}

Pada perhitungan biaya maintenance, didapatkan melalui perkalian antara cost maintenance dengan frekuensi maintenance.

Tabel 14. Biaya Maintenance Eksisting

\begin{tabular}{|c|c|c|c|}
\hline Komponen & $\mathrm{Fm}$ & $\mathrm{Cm}$ & $\begin{array}{c}\text { Biaya } \\
\text { Maintenance }\end{array}$ \\
\hline \multirow[b]{2}{*}{ Pillow } & \multirow{2}{*}{2} & $\mathrm{Rp}$ & $\mathrm{Rp}$ \\
\hline & & 5.285 .817 & 10.571 .633 \\
\hline \multirow[t]{4}{*}{ Block } & \multirow{2}{*}{2} & $\mathrm{Rp}$ & $\mathrm{Rp}$ \\
\hline & & 5.285 .817 & 10.571 .633 \\
\hline & \multirow{2}{*}{4} & $\mathrm{Rp}$ & $\mathrm{Rp}$ \\
\hline & & 6.195 .567 & 24.782 .267 \\
\hline \multirow{4}{*}{$\begin{array}{l}\text { Besi } \\
\text { Molding }\end{array}$} & \multirow{2}{*}{4} & $\mathrm{Rp}$ & $\mathrm{Rp}$ \\
\hline & & 6.195 .567 & 24.782 .267 \\
\hline & \multirow{2}{*}{4} & $\mathrm{Rp}$ & $\mathrm{Rp}$ \\
\hline & & 6.195 .567 & 24.782 .267 \\
\hline \multirow{6}{*}{ Rantai } & \multirow{2}{*}{3} & $\mathrm{Rp}$ & $\mathrm{Rp}$ \\
\hline & & 5.239 .767 & 15.719 .300 \\
\hline & \multirow{2}{*}{3} & $\mathrm{Rp}$ & $\mathrm{Rp}$ \\
\hline & & 5.239 .767 & 15.719 .300 \\
\hline & \multirow{2}{*}{ Total } & & $\mathrm{Rp}$ \\
\hline & & & 126.928 .667 \\
\hline
\end{tabular}

Tabel 15. Biaya Maintenance Usulan

\begin{tabular}{|c|c|c|c|}
\hline Komponen & Fm & $\mathrm{Cm}$ & $\begin{array}{c}\text { Biaya } \\
\text { Maintenance }\end{array}$ \\
\hline \multirow[b]{2}{*}{ Pillow } & \multirow{2}{*}{2} & $\mathrm{Rp}$ & $\mathrm{Rp}$ \\
\hline & & 5.285 .817 & 10.571 .633 \\
\hline \multirow[t]{4}{*}{ Block } & \multirow{2}{*}{1} & $\mathrm{Rp}$ & $\mathrm{Rp}$ \\
\hline & & 5.285 .817 & 5.285 .817 \\
\hline & \multirow{2}{*}{2} & $\mathrm{Rp}$ & $\mathrm{Rp}$ \\
\hline & & 6.195 .567 & 12.391 .133 \\
\hline \multirow{4}{*}{$\begin{array}{c}\text { Besi } \\
\text { Molding }\end{array}$} & \multirow{2}{*}{2} & $\mathrm{Rp}$ & $\mathrm{Rp}$ \\
\hline & & 6.195 .567 & 12.391 .133 \\
\hline & \multirow{2}{*}{2} & $\mathrm{Rp}$ & $\mathrm{Rp}$ \\
\hline & & 6.195 .567 & 12.391 .133 \\
\hline \multirow{4}{*}{ Rantai } & \multirow{2}{*}{3} & $\mathrm{Rp}$ & $\mathrm{Rp}$ \\
\hline & & 5.239 .767 & 15.719 .300 \\
\hline & \multirow{3}{*}{1} & $\mathrm{Rp}$ & $\mathrm{Rp}$ \\
\hline & & 5.239 .767 & 5.239 .767 \\
\hline Total & & & $\mathrm{Rp}$ \\
\hline
\end{tabular}

73.989 .917

Tabel 16. Perbandingan Biaya Maintenance

\begin{tabular}{cc} 
Maintenance & Cost Maintenance \\
\hline Eksisting & Rp 126.928 .667 \\
Usulan & Rp 73.989 .917 \\
\hline
\end{tabular}

Pada tabel 16 adalah perbandingan biaya maintenance, didapatkan biaya maintenance usulan yang lebih rendah sebesar Rp 52.938.750 dibandingkan dengan biaya maintenance eksisting perusahaan. Hal ini disebabkan karena perusahaan belum menerapkan metode RRCM dalam melaksanakan kegiatan pemeliharaan. Kegiatan pemeliharaan yang dilakukan di PT. XYZ masih berdasarkan perkiraan engineer seperti menentukan frekuensi pemeliharaan, data umur komponen, dan kerusakan komponen.

Oleh karena itu, perusahaan harus menerapkan metode RRCM dalam melakukan kegiatan pemeliharaan, khususnya membuat jadwal pemeliharaan yang tetap dan menerapkan interval waktu untuk melakukan pemeliharaan komponen mesin yang sudah ditetapkan sehingga dapat menghemat biaya pemeliharaan dalam memperbaiki mesin. 


\section{KESIMPULAN}

Penelitian ini pada dasarnya membahas tentang kebijakan pemeliharaan mesin, khususnya penentuan jadwal pemeliharaan, interval waktu pemeliharaan, dan mengoptimalkan biaya pemeliharaan di PT. XYZ menggunakan metode RRCM.

Hasil penelitian ini menunjukkan bahwa terdapat 3 komponen yang sering rusak yaitu pillow block, besi molding, dan rantai. Jadwal pemeliharaan untuk setiap komponen kritis didapat 7 proposed maintenance task diantaranya 2 schedule on-condition task, 3 schedule restoration task, dan 2 schedule discard task. Untuk komponen pillow block interval waktu pemeliharaan dilakukan setiap 7 bulan sekali dengan melakukan pengecekan dan setiap 9 bulan sekali melakukan penggantian komponen. Untuk komponen besi molding dilakukan restorasi selama 11 bulan sekali. Dan untuk komponen rantai dilakukan pemeliharaan setiap 4 bulan sekali dengan melakukan pengecekan dan setiap 8 bulan sekali melakukan penggantian komponen. Selain itu, perusahaan PT. XYZ dapat melakukan penghematan biaya pemeliharaan sebesar $41,7 \%$ dari biaya eksisting saat ini.

Untuk penelitian selanjutnya bisa memperhitungkan dari sisi reliability sparepart dengan metode RCS.

\section{DAFTAR PUSTAKA}

Afiva, W. H., Atmaji, F. T. D., \& Alhilman, J. (2019). Usulan Interval Preventive Maintenance dan Estimasi Biaya Pemeliharaan Menggunakan Metode Reliability Centered Maintenance dan FMECA. Jurnal Ilmiah Teknik Industri, 18(2), 213-223. https://doi.org/10.23917/jiti.v18i2.8551

Alhilman, J., Atmaji, F., \& Athari, N. (2017). Software Application for Maintenance System. 2017 Fifth International Conference on Information and Communication Technology (ICoICT), O(RCM II), 470-475.

Alrifaey, M., Hong, T. S., As'arry, A., Supeni, E. E., \& Ang, C. K. (2020). Optimization and selection of maintenance policies in an electrical gas turbine generator based on the hybrid reliability-centered maintenance (RCM) model. Processes, 8(6). https://doi.org/10.3390/PR8060670
AS/NZS 4360. (1999). Risk Management. In Standards Australia, Sydne. http://www.epsonet.eu/mediapool/72/723 588/data/2017/AS_NZS_43601999_Risk_management.pdf

Atmaji, F. T. D. (2015). Optimasi Jadwal Perawatan Pencegahan Pada Mesin Tenun Unit Satu Di Pt Ksm, Yogyakarta. Jurnal Rekayasa Sistem \& Industri (JRSI), 2(02), 7-11. //jrsi.sie.telkomuniversity.ac.id/JRSI/arti cle/view/83

Atmaji, F. T. D., \& Alhilman, J. (2018). A framework of wireless maintenance system monitoring: A case study of an automatic filling machine at SB company. 2018 6th International Conference on Information and Communication Technology, ICoICT 2018, O(c), 227-232. https://doi.org/10.1109/ICoICT.2018.852 8722

Atmaji, F. T. D., Noviyanti, A. A., \& Juliani, W. (2017). Implementation Of Maintenance Scenario For Critical Subsystem In Aircraft Engine Case study: NTP CT7 engine. International Journal of Innovation in Enterprise System, 2(01), 50-59.

https://doi.org/10.25124/ijies.v2i01.17

Basanta, F. A., Alhilman, J., \& Musnansyah, A. (2017). Perancangan Aplikasi Analisis RCM ( Reliability Centered Maintenance ) Dan RCS ( Reliability Centered Spares ) Dalam Menentukan Kebijakan Maintenance Dan Persediaan Spare Part. E-Proceeding of Engineering, 4(2), 2867-2874.

Dhamayanti, D. S., Alhilman, J., \& Athari, N. (2016). Usulan Preventive Maintenance Pada Mesin Komori Ls440 Dengan Menggunakan Metode Reliability Centered Maintenance (Rcm Ii) Dan Risk Based Maintenance (Rbm) Di Pt Abc. Jurnal Rekayasa Sistem \& Industri (JRSI), 3(02), 31. https://doi.org/10.25124/jrsi.v3i02.29

Fang, F., Zhao, Z. J., Huang, C., Zhang, X. Y., Wang, H. T., \& Yang, Y. J. (2019). Application of reliability-centered maintenance in metro door system. IEEE Access, 7, 186167-186174. https://doi.org/10.1109/ACCESS.2019.2 960521 
Gupta, G., Mishra, R. P., \& Singhvi, P. (2016). An Application of Reliability Centered Maintenance Using RPN Mean and Range on Conventional Lathe Machine. International Journal of Reliability, Quality and Safety Engineering, 23(6). https://doi.org/10.1142/S0218539316400 106

Holgado, M., Macchi, M., \& Fumagalli, L. (2016). Value-in-use of e-maintenance in service provision: survey analysis and future research agenda. IFACPapersOnLine, 49(28), 138-143. https://doi.org/10.1016/j.ifacol.2016.11.0 24

Igba, J., Alemzadeh, K., Anyanwu-Ebo, I., Gibbons, P., \& Friis, J. (2013). A systems a Reliability-Centred Maintenance (RCM) of wind turbines. Procedia Computer Science, 16, 814-823. https://doi.org/10.1016/j.procs.2013.01.0 85

Joel Levitt. (2008). Lean Maintenance. https:/www.amazon.com/Joel-LevittMaintenance-2008-08-15Hardcover/dp/B00IH6YXES

Khorshidi, H. A., Gunawan, I., \& Ibrahim, M. Y. (2015). Reliability centered maintenance using system dynamics approach. Proceedings of the IEEE International Conference on Industrial Technology, 2015-June(June), 1932-1936. https://doi.org/10.1109/ICIT.2015.71253 79

Kullawong, T., \& Butdee, S. (2015). Integrating reliability-centered maintenance with cost optimization \& application in plant of hard chrome plating. International Journal of Industrial Engineering and Management, 6(2), 85-92.

Lienig, J., \& Bruemmer, H. (2017). Fundamentals of electronic systems design. In Fundamentals of Electronic Systems

Design. https://doi.org/10.1007/978-3-31955840-0

Márquez, A. C. (2007). The maintenance management framework: models and methods for complex systems maintenance. Springer series in reliability engineering.

Niu, G., Yang, B. S., \& Pecht, M. (2010). Development of an optimized conditionbased maintenance system by data fusion and reliability-centered maintenance. Reliability Engineering and System Safety, 95(7), 786-796. https://doi.org/10.1016/j.ress.2010.02.01 6

Okwuobi, S., Ishola, F., Ajayi, O., Salawu, E., Aworinde, A., Olatunji, O., \& Akinlabi, S. A. (2018). A reliability-centered maintenance study for an individual section-forming machine. Machines, 6(4). https://doi.org/10.3390/machines604005 0

Rahmadhanty, S. F., Pitana, T., \& Siswantoro, N. (2019). Reviewing the ReliabilityCentered Maintenance on Cooling Water Pump of LNG Production Company. International Journal of Marine Engineering Innovation and Research, 3(3). https://doi.org/10.12962/j25481479.v3i3. 4826

Selvik, J. T., \& Aven, T. (2011). A framework for reliability and risk centered maintenance. Reliability Engineering and System Safety, 96(2), 324-331. https://doi.org/10.1016/j.ress.2010.08.00 1

Sinha, R. S., \& Mukhopadhyay, A. K. (2015). Reliability centered maintenance of cone crusher: a case study. International Journal of Systems Assurance Engineering and Management, 6(1), 3235. https://doi.org/10.1007/s13198-0140240-7 